\title{
TAXATION IN THE ALCOHOLIC BEVERAGE FIELD
}

\author{
Charles F. Conlon*
}

Alcoholic beverages and the traffic in them have always been well-recognized objects of taxation. Both as a revenue producer and as a means of curtailing the consumption of these beverages the tax upon them has been in use for a long time and in many countries. ${ }^{1}$ In this country before the Revolution, import duties on spirituous liquors were common in all the southern colonies and the New England colonies, and New York taxed their manufacture and sale. ${ }^{2}$ During the Revolution, New York, Pennsylvania and some of the southern states were loath to impose direct taxes but they did raise revenue from liquor and other excises; while in the period shortly after the Revolution, liquor and other internal excises were an important component of state revenues. ${ }^{3}$

During the Confederation a proposal that the central government levy an excise on liquor made no headway. But only two years after the ratification of the Constitution our first national tax bill, a customs measure, included import duties on liquors. Two years later, in I79r, the first national internal excises included a tax on whiskey. The whiskey tax was discontinued in $x 802$ and it was not until the exigencies of the War of I8I2 demanded that more revenue be raised that liquor was again taxed. Revenues from import duties declined sharply in the years after I8Ir, and the special session of Congress in $x 8 \mathrm{r}_{3}$ imposed license taxes on stills and on the retailing of both wines and spirituous liquors. ${ }^{4}$ After a few years the tax was again abandoned, not to be used again until in 1862, when Civil War financing began to present an acute problem. From that time, up to the present, we have had national taxes of one type or another on alcoholic beverages.

The states and local governments also levied taxes on the traffic in alcoholic beverages but these taxes were in the nature of license or occupational taxes rather than excises on production or sales as was the federal tax. As a matter of fact, in the prosperous days of the I790's when the states were receiving large incomes from their holdings of federal bonds, state bank stocks, sales of public land and confiscated loyalist properties, the liquor tax was one of the few that was generally kept in effect. ${ }^{5}$

* LL.B., 1938, George Washington University. Member of the District of Columbia Bar. Assistant Director, Federation of Tax Administrators, Chicago, Illinois.

${ }^{1}$ See the summary statement in the Wickersham Report. Nat. Comm. on Law Obs. and Enf., Report on the Enforcement of Prohibition Laws of the United States, H. R. Doc. No. 722, 7rst Cong. 3rd Sess. (1931) 3; Twentieth Century Fund, Facing the Tax Problem (1937) I99.

${ }_{2}^{2}$ Shultz and Caine, Financial. Developaient of the United States (i937) i7-i 8.

${ }^{3}$ Id. 65,79 .

II. $14 \mathrm{I}$.

"Id. 118 . 


\section{The Theory of Alcoholic Beverage Taxation}

It is commonly said that there are two principal aspects of alcoholic beverage taxation. These are its revenue and sumptuary aspects. The former is concerned with the yield alone of the tax. The latter involves the idea that the citizens' expenditures for certain types of goods deemed socially harmful should be limited by the government. Formerly the term sumptuary taxation was applied to those taxes laid on goods of a type not indispensable to human well-being and it comprehended, therefore, many taxes which today are called luxury taxes. The idea that too many luxuries, per se, are not good for the citizen has largely disappeared from present thought and our luxury taxes are based on the premise that a person who can afford to buy them can afford to pay the tax. Sumptuary taxation, therefore, is limited in meaning to taxation calculated to control and limit the consumption of goods from the use of which a real social harm is apprehended. ${ }^{6}$

The notion that the consumption of alcoholic beverages is something that should be regulated by the state is nothing new, and for that matter, neither is the strong resentment to this type of control which developed in the period immediately prior to the ratification of the Twenty-first Amendment. When our first whiskey tax was enacted in I79r, pamphleteers of the time sharply criticized and satirized the general theory of sumptuary taxation. One suggested that it would be wiser to tax the more prevalent vices of perjury, slander and infidelity. ${ }^{\top}$ Apropos of using the federal power to tax for this purpose the Chairman of the first National Revenue Commission of the United States, and later Special Commissioner of the Revenue, said:8 "... where Congress assumes that the consumption or use of certain commodities is prejudicial to the interests of the people ... and attempts, when providing means for the support of the Federal administration, to embody such assumptions, with a view of prohibitions or restraints, in measures of revenue, it is also enacting sumptuary laws and imposing taxes, not in accordance with any rule of equity, but by reason of some arbitrary and sentimental notions of how a citizen ought to live, dress, eat and drink."

Aside from the questions of social evil and of the wisdom of using the tax power for its control or eradication, there has even been disagreement on what was formerly the principal inquiry, whether alcoholic beverages are of the "luxury" or "indulgence" type of commodities. As a matter of fact, in his Lectures and also in the first edition of his classic Wealth of Nations, Adam Smith seemed to class beer as a necessity, although in the fifth edition he says beer and ale in Great Britain and wine even in the wine countries are luxuries. ${ }^{9}$ When Hamilton proposed the enactment of the first internal excises of the national government on the consumption of luxuries he

\footnotetext{
'Twentieth Centurx Fund, op. cit. supra note 1 , at 195.

${ }^{7}$ Shultz and Caine, op. cit. supra note 2 , at 108.

${ }^{8}$ Wells, The Theory and Practice of Taxation (1907) 256. See also Twentieth Century Fund, op. cit. stupra note $\mathrm{I}$, at $5 \mathrm{I}$.

${ }^{\circ}$ Smith, Lectures on Justice, Police, Revenue and Arms (Cannan ed. 1896); An Inquiry into the Nature and Cause of the Wealth of Nattons (Cannan ed. 1904) Bk. 5, c.3, n. 73.
} 
met with bitter opposition. The tax on whiskey, in particular, was attacked as a tax not on a luxury, but on a poor man's necessity. Whatever the merits of the case were, the tax itself was strongly resisted, especially in the rural and southern sections of the country and in spite of successive reductions in rate, President Washington was finally forced to send troops to western Pennsylvania to suppress what was known as the Whiskey Rebellion. ${ }^{10}$

In discussing the use of taxation to control or limit the consumption of alcoholic beverages, it may be pointed out that at the present time by far the greater part of both federal and state alcoholic beverage revenues are derived from excise taxes levied on a gallonage basis. Since this type of tax hits the lower income consumer much more effectively than the higher bracket man, it will have its strongest deterrent effect on the former class. Proponents of strict control through taxation would be quick to point out, in justification of such a tax, that it is among the members of the lower income brackets that the social problems of liquor are most acute.

While the ordinary general sales tax is termed regressive, the liquor excise results in pyramiding to a much greater extent. The federal tax on spirits is paid on withdrawal from storage and is added then to the production cost. When the consumer finally purchases the beverage this total cost, including the tax, has undergone several markups. The consumer pays a price which includes a profit on the amount of tax similar to the profit on any other ingredient or service which enters into the price of the finished article. The same is true, to a more limited extent, of the state excises. If the importing distributor or wholesaler stamps the bottle this tax, too, becomes a part of the price to the retailer and is included in the base on which he makes his mark-up.

\section{Recommendations for Post-Repeal Taxation}

It is true that pre-Repeal discussion, especially in 1930-32, placed great stress on the revenue possibilities inherent in the return of the alcoholic beverage traffic. That phase undoubtedly had great popular appeal in a period of declining tax revenues and mounting governmental deficits. But other persons were keenly aware of the social aspects of Repeal and of the tax policies which would become operative in the near future. The Liquor Study Committee began one inquiry. The resulting report known variously as the Fosdick-Scott Report after the members who conducted the study, and the Rockefeller Liquor Report after John D. Rockefeller, Jr., who initiated and arranged the financing of the study, made several recommendations regarding the taxation of alcoholic beverages. ${ }^{11}$ Stated generally, the tenor of the report's tax recommendations was that "the fundamental motives should be broadly social, not narrowly fiscal."12

To the same effect was a resolution of the Interstate Commission on Conflicting Taxation adopted at Washington: ${ }^{13}$ "It is the sense of the Commission ... (I) that

\footnotetext{
${ }^{10}$ Shultz and Caine, op. cit. supra note 2, at 108, iro.

${ }^{11}$ Fospick and Scotr, TOWARd Liquor Contror (1933). $\quad{ }^{12} I d .108$.

${ }^{13}$ Joint Hearings on Tax on Intoxicating Liquor before the House Committee on Ways and Means
} 
the social implications of the repeal of the Eighteenth Amendment greatly outweigh in importance the revenue aspects of repeal. (2) That the taxes on alcoholic liquors, as well as the taxes and license fees upon the traffic in such liquors, should be so devised as to promote temperance, and at the same time to discourage illicit trafficking in such beverages." The Commission was composed of state revenue officials and legislators and numbered among its members five well-known state revenue administrators of the present time.

Representatives of every type of interest testified at the joint hearings held in Washington by the House Committee on Ways and Means and the Senate Committee on Finance to consider the impending alcoholic beverage tax bill. As would be imagined, their recommendations as to objectives, rates and methods varied widely. Some of the federal officials stressed as objectives of the tax to be adopted, first the displacement of the bootlegger, and second, the matter of revenue..$^{14}$

Among those who discussed the question of the social implications of the repeal of Prohibition and the taxation of alcoholic beverages to follow, there was agreement in principle on the fact that the chief control to be desired was that over distilled spirits or other beverages of high alcoholic content. Of this, the Fosdick-Scott Report said: $:^{15}$ "The experience of every country supports the idea that light wines and beers do not constitute a serious social problem."

On the whole, the recommended tax policies looked to the high taxation of spirits and to a moderate rate of taxation on the lighter beverages on the theory that the consumption of the latter in preference to spirits would be promoted. Taxation of spirits and wine according to their alcoholic content was more than once suggested. It was also proposed to make the rate on fermented malt beverages vary as to alcoholic content. From the attitude of members of Congress to this proposal, however, it seems that they regarded fermented malt beverages generally similar within reasonable limits, and that a tax graduated in rather small percentages would create discriminations among members of the same industry. ${ }^{16}$

In one important particular the Fosdick-Scott Report, the Interstate Commission on Conflicting Taxation, and the Interdepartmental Committee (an informal committee of federal administrative officials reporting to the Secretary of the Treasury) made similar recommendations. This was in the matter of co-ordinating federal and state taxation of alcoholic beverages in order to prevent a duplication of taxes that would make it easier for the bootlegger to compete. The suggested system was for one gallonage tax, federally collected, to be shared between the Federal Government and the states. The Interdepartmental Committee suggested that $20 \%$ of the yield be returned to the states. ${ }^{17}$ The Interstate Commission on Conflicting Taxation sug-

\footnotetext{
and the Senate Committee on Finance, 73rd Cong. interim Ist and 2nd Sess. (1933) 244. Hereinafter cited as Joint Hearings.

${ }^{14} I d .79,157$; and especially the Interdepartmental Report to the Secretary of the Treasury, 308309,331 ,

${ }^{25}$ Fosdick AND ScOTT, op. cit. supra note II, at 18.

${ }^{30}$ E.g., Joint Hearings, 160. ${ }^{17}$ Id. 338 .
} 
gested the amount returned be $50 \%{ }^{18}$ The personnel of the Fosdick-Scott study commission felt that not less than $20 \%$ of the yield should be returned. ${ }^{10}$ The formulas by which the distribution among the states would be made differed in one principal respect, for the Interdepartmental formula would have included a production factor in addition to the wet-dry area basis. ${ }^{20}$

In addition to the fiscal-sumptuary aspects of the taxation of alcoholic beverages, there was the complicating factor of the bootlegger to be considered. During the years in which the country had Prohibition, the illicit liquor trade had grown to tremendous proportions. Many witnesses at the Congressional hearings spoke of its compact organization, its ability to produce liquor on a fairly low cost basis and the difficulty of competing with the illegal trade if legal liquor could not be sold at a fairly low price. This factor, therefore, was also an important consideration in the tax rate deliberations.

\section{The Present and Pre-Prohibition Taxation of Alcoholic Beverages}

The proposals that the Federal Government impose only excise taxes, that the states impose only occupational license taxes, and that localities levy no taxes, urged at various times by students of post-Repeal taxation, did not become effective. Under the form that alcoholic beverage taxation has actually taken, we find the three levels of government taxing either the beverage or the trade or both.

The Federal Government imposes an excise tax on distilled spirits, wines, and beers. Imported spirits, wines and beers pay in addition a customs duty. There are numerous special or occupational taxes on rectifiers, brewers, and wholesale and retail dealers in all types of alcoholic beverages. The states impose excise taxes on gallonage of all types of alcoholic beverages and also collect miscellaneous license fees. Local governments, counties, cities, towns and villages are often empowered to license the sale of alcoholic beverages and in some instances to lay an excise measured by gallonage.

(a) Federal Taxes. The excise tax is the backbone of the federal system of alcoholic beverage taxation. In $x 939$ these taxes accounted for $\$ 523,458,285$ out of a total liquor tax revenue of $\$ 587,799,700 .{ }^{21}$ From Repeal until June 30 , $193^{8}$, the excise on distilled spirits was $\$ 2.00$ per taxable gallon. Effective that date, it was raised to $\$ 2.25$ except on brandy which remained at $\$ 2.00$. Then, effective July I, 1940, the rate on all distilled spirits was raised to $\$ 3.00$ and brandy was increased to $\$ 2.75$ per gallon. The increase of 75 c, effective for five years only, was imposed in the Revenue Act of $1940^{22}$ to help defray the additional expenditures authorized for the national defense. In addition to the excises, there is also a rectification tax of $30 \mathrm{c}$ per gallon.

The present rate of tax on distilled spirits is nearly three times the ordinary preProhibition rate of \$r.o. However, it is not quite half as great as our highest previous rate of $\$ 6.40$ per taxable gallon of beverage alcohol. This rate, imposed

${ }^{18}$ Id. 244.

${ }^{20}$ Id. $244,338,346$.

22 Pub. L. No. 656, 76th Cong., 3rd Sess. (1939).
${ }^{10}$ Id. $151-155$.

${ }^{21}$ Rep. Commissioner INT. Rev. (1939) 97. 
by the Revenue Act of IgI8, passed in February I9I9, was really a penalty, because, although the Eighteenth Amendment was not effective until January x6, I920, thirty-two states were dry and there was practical prohibition under Presidential proclamation. The next highest tax of $\$ 3.20$ on beverage spirits was in the period immediately preceding, from October 3 , I9I7, to February 25, r $919 .{ }^{23}$

Wine taxes are comparatively inconsequential as revenue producers. The rates on wine as of June 30 , 1940, ranged from 5 to $20 \mathrm{c}$ per gallon on still wines and from $\mathrm{r}^{1 / 4}$ to $2 \frac{1}{2} \mathrm{c}$ per half pint ( 20 to 4 oc per gallon) on cordials and artificially carbonated and sparkling wines. These rates are close to those imposed before Prohibition. The first rates on wine after Repeal, however, were considerably higher, ranging from ro to $40 \mathrm{c}$ on still wines. These original rates were reduced $50 \%$ in 1936 .

Such a reduction seemed to indicate a policy of encouraging the use of lighter alcoholic beverages, since, because of its bulk and low alcoholic content, there is no great inducement for bootleggers to traffic in wine. For the latter reason, taxes on it may be laid with an eye to revenue primarily. In spite of the appeal of this interpretation of policy, it is questionable, for wine received two boosts in the applicable tax rate effective July $\mathrm{I}$, I940, the first raising the 10c bracket to $15 \mathrm{C}$ and the $20 \mathrm{C}$ bracket to $25 \mathrm{c}^{24}$ Then the Revenue Act of 1940 increased all wine taxes, resulting in a present range of rates from 6 to $30 \mathrm{c}$ per gallon on still wines and of from $\mathrm{r} 1 / 2$ to $3 \mathrm{c}$ per half pint ( 24 to $48 \mathrm{c}$ per gallon) on cordials and artificially carbonated and sparkling wines.

Prior to $\mathrm{IgI}_{4}$ wine produced from domestic grapes was not taxed. In that year a tax of $8 \mathrm{c}$ per gallon was imposed on all domestic and imported still wines. ${ }^{25}$ In rgr6 the tax was revised according to the alcoholic content of the wines, and those of not more than $14 \%$ alcoholic content paid $4 \mathrm{c}$ per gallon. In Igrg these rates were greatly increased. Wines over $24 \%$ are now taxed as distilled spirits. They are the only example in the federal system where a distinction based on alcoholic content is made in the rate of tax.

The federal excise on beer from Repeal to July of this year was $\$ 5.00$ per barrel of $3^{\mathrm{r}}$ gallons. Under the Revenue Act of $194^{\circ}$ it was increased $\$ 1.00$ for the next five years. The present rate of $\$ 6.00$ is six times as high as the ordinary pre-Prohibition tax of $\$ 1.00$ per barrel which was in effect from 1902-1914. From 19I4-19I7 the rate was $\$ 1.50$ and in the $1917-\mathrm{IgI} 8$ period it was increased to $\$ 3.00$ and on February I9I9 to $\$ 6.00$. This latter increase, however, was in the interim before the effective date of the Eighteenth Amendment.

In addition to the internal excises on spirits, wine and beer import duties are also collected by the Federal Government. Imported products are subject to both the duties and the excises. Prior to October 4, I9I7, the internal excises were not applied to such imports. The duty on spirits was $\$ 2.60$ per proof gallon, on still wines under $14 \%, 45^{\mathrm{C}}$ per gallon, over $\mathrm{x} \%$, 6oc per gallon, and on beer, 23 to $45^{\mathrm{C}}$ per

${ }^{33}$ See table of statutory citations, Joint Hearings, 372.

34 Pub. L. No. 655, 76th Cong., 3rd Sess. (1939). $\quad{ }^{25} 38$ Stat. 746. 
gallon depending on the type of container. In October IgI7 spirits were first subjected to the double impost. The present duty on spirits is $\$ 5.00$ per gallon but numerous trade agreements have resulted in reductions, and the same is true of the wine duties. Fermented malt beverages pay $\$ \mathrm{x} .00$ per gallon duty plus the excise of I6c per gallon.

(b) State and Local Taxes. The Twenty-first Amendment as construed by the Supreme Court returned the regulation of liquor traffic to the states. Under this construction the power of the states to tax the alcoholic beverage traffic was considerably widened for the restrictions of the commerce clause no longer bound them. ${ }^{26}$ As a matter of practice, however, practically all states exempt shipments delivered outside of the state from their excise taxes. As far as the states' power to impose excises on local sales of liquor was concerned, the Amendment caused no changes since the states always had this power unless their own constitutions prohibited it.

All of the license-control states now impose excise taxes on spirits, wine and beer just as the Federal Government does. All of the monopoly states impose excises on beer, and Michigan, Ohio, Oregon, Pennsylvania, Vermont, Washington and Wyoming have in addition an excise on wine. Seven of the monopoly states, Maine, Montana, Ohio, Pennsylvania, Vermont, Washington and Wyoming, have special sales or excise taxes on distilled spirits sold by state stores or agencies. ${ }^{27}$ Effective July r, r 940 , Virginia added a 10\% tax on sales by the Beverage Control Board.

The rate of tax on distilled spirits ranges from $40 \mathrm{c}$ per gallon in Nevada and $50 \mathrm{C}$ in Illinois to $\$ 1.60$ in Colorado, $\$ 2.00$ in Delaware, New Mexico and Vermont, and $\$ 2.20$ in Maine. In Rhode Island the excise on imported distilled spirits is $\$ 1.00$ per gallon but on domestic spirits the rate is among the lowest, 50c. Massachusetts until a year ago had a $40 \mathrm{C}$ tax but it has been increased to $95 \mathrm{c}$ for a period of two years ending in $194 \mathrm{r}^{28}$

The rate of excise on wine ranges from a low of one cent per gallon in California and five cents in Arkansas to a high of $75 \mathrm{c}$ in Florida, $80 \mathrm{c}$ in Arizona and $\$ \mathrm{r} .00$ in Minnesota. Vermont has a state store tax on fortified wine which amounts to $\$ 1.00$ per gallon. In some states the tax on wine is equal to the tax on distilled spirits. This is similar to federal law under which wines containing over $24 \%$ alcohol by volume are taxed as distilled spirits. In some states the rates are moderate and there is little range in them. For example, in Illinois the rates on wine are from ro to 20c. In the District of Columbia there is no tax on still wines of under $14 \%$ alcohol.

The excise on beer likewise shows great variations ranging from $2 c$ per gallon (62c per $3^{\mathrm{I}}$ gallon barrel) in California, Illinois, Missouri, Nevada and Wyoming to

${ }^{20}$ State Board of Equalization v. Young's Market, 299 U. S. 56 (1936). Sec also Indiana Brewing Co. v. Liquor Control Comm., 305 U. S. 39I (1939); Joseph S. Finch \& Co. v. McKittrick, 305 U. S. 395 (r939).

${ }^{27}$ No consideration is given in this paper to revenues of the monopoly states except in so far as they impose taxes on the alcoholic beverage traffic. Most of these states, however, derive their principal alcoholic beverage revenues from sales mark-ups.

${ }^{28}$ State tax rates taken from the statistical summaries of the Distilled Spirits Institute, Pablic Revenues from Alcoholic Beverages, 1937, 1938, 1939. 
$\$ 6.6 \mathrm{I}$ per barrel in Mississippi where the tax is laid at the rate of 2I.34c per gallon. Several other states have high taxes on beer, including Maine, I6c per gallon or $\$ 4.96$ per barrel; Georgia, $\$ 4.5^{\circ}$ per barrel, and North Carolina, $\$ 3.75$ per barrel. South Carolina taxes beer at ${ }_{15} \mathrm{C}$ per gallon or $\$ 4.65$ per barrel, and, when it is sold in quantities of 6 ounces or under, at the rate of Ic for six ounces or $\$ 6,6 \mathrm{I}$ per gallon.

These excises on spirits, wine and beer are a post-Repeal development in state taxation. Before Prohibition the states had only occupational taxes on this traffic and left the excise taxation to the Federal Government. Pressure for revenue coupled with the little headway made on the federally-collected state-shared tax proposals soon made it evident that the states would not return to their pre-Prohibition system of taxation.

Shortly after Repeal proposals were made for special income taxes on the alcoholic beverage industry. This was advocated from the viewpoint of social control on the theory that such a tax would act as a brake on an aggressive sales policy by weakening the profit motive. ${ }^{29}$ Apparently no state has enacted such a tax.

Several states, however, do impose special sales taxes in addition to the regular excises. These are: Arkansas, which levies a special tax of $3 \%$ on the wholesale price of spirituous and vinous liquors; North Dakota, a tax of $7 \%$ of the sale price on alcoholic beverages of 4 to $24 \%$ alcohol and $8 \%$ on beverages of 24 to $50 \%$ alcohol; and South Dakota, a special tax of $10 \%$ of the gross receipts of distillers, manufacturers and wholesalers from sales of intoxicating liquor and high point beer. Fifteen states having general sales taxes also require that this tax be collected on sales of alcoholic beverages. Six of these are monopoly system states. In addition to these states, New York City also collects its retail sales tax on sales of alcoholic beverages. A new law in Virginia is worthy of note in that it includes a tax differential on beer sold at a price over ten cents. It provides that where beer is sold in bottles of I2 ounces or less the tax is IC if the price is Ioc or under but if sold for more than IOC the $\operatorname{tax}$ is $50 \%$ higher or $\mathrm{I} 1 / 2 \mathrm{c}^{30}$

Localities in a few instances also have the power to impose excises. New Orleans, in addition to local license fees, collects a tax of $40 c$ per gallon on distilled spirits, 5 to $40 \mathrm{c}$ on wines and $40 \mathrm{c}$ per barrel on beer. Garrett County, Maryland, has a tax of 2c per pint bottle of beer. Incorporated cities and towns in Arizona are apparently empowered to license and tax the manufacture, sale and disposal of alcoholic beverages, while in Utah, counties and incorporated cities and towns may license and tax the sale of light beer at retail.

Forty-seven states have license fees of some type. Rhode Island collects license fees but the money collected goes to the city or town where the licensed premises are located. The licenses issued by the states include some or all of the following: distillers, rectifiers, blenders, winers, brewers, beer, wine and spirits wholesalers and retailers, package stories, hotels, night clubs, caterers, restaurants, drug stores, clubs,

${ }^{20}$ Joint Hearings, 161; Fosdick AND ScorT, op. cit. supra note II, at I24.

${ }^{30}$ Laws 1940 , H. B. 1 42. 
warehouses, still manufacturers, brokers, nonresident manufacturers, common carriers and others. In Public Revenues from Alcoholic Beverages, $1939,{ }^{31}$ the number of different state license fees for which revenue receipts are given range from $2 \mathrm{I}$ in California, 20 in Missouri and Oregon, and 18 in Michigan, New York and Pennsylvania, to 5 in Idaho, Nebraska, South Carolina and West Virginia and 3 in Utah and Kansas. These license fees vary greatly in cost, from a low of $\$$ r.0o on domestic wine manufacturers in Arkansas to a high of $\$ 7,500$ on distillers in New York.

Fixing the license fees for various types of sellers has been suggested as a method of controlling the traffic in alcoholic beverages. One study in which this point is examined says, however, that in most of the states no definite aim is revealed in the imposition of the license fee. ${ }^{32}$

\section{Taxation and the Consumption of Alcoholic Beverages}

The excise yields on various alcoholic beverages afford one means of calculating their consumption. During the calendar years 1937, 1938 and 1939 all of the states, monopoly and license, derived revenues from alcoholic beverage taxes. On the basis of these revenues the consumption of alcoholic beverages dipped as did other lines of consumers goods in the recession of 1938 .

These revenues declined $\$ 12,000,000$ in 1938 and came back $\$ 17,000,000$ in 1939 . License fee revenues increased in $193^{8}$ but dropped sharply in 1939 , probably reflecting a lesser number of renewals following a year of decreased sales. State monopoly sales declined $\$ 16,000,000$ in 1938 but recovered only $\$ 12,000,000$ in 1939. Net state revenues of all kinds from alcoholic beverages declined $\$ 17,000,000$ in $193^{8}$ and in I939 gained slightly more than that amount. ${ }^{33}$ This $x 938$ figure represents a decline of about $6 \%$ as compared with a drop of about $10 \%$ in the national income during that year. ${ }^{34}$

The same trend is noticeable in total federal internal revenue and import duty yields which declined about $\$ 32,000,000$ in 1938 and increased $\$ 35,000,000$ in $1939 .^{35}$ It is notable, however, that excise yields on distilled spirits increased in each of these calendar years. This was due to the $25 \mathrm{c}$ per gallon increase in tax which was effective July $\mathrm{I}, 1938$. On a fiscal year basis, federal yields on distilled spirits followed the state revenue pattern, declining \$10,000,000 in 1938 from the 1937 figure. $^{36}$

During this period, on the basis of calendar year federal figures, wine tax yields were increasing, being slightly more in 1938 than in 1937 , and about $14.5 \%$ higher in $x 939$ than in 1938 .

In this same period federal beer taxes were about $\$ 75^{0,000}$ less in $x 939$ than in 1937, having dropped $\$ 22,000,000$ in 1938 under the 1937 figures.

${ }^{31}$ Supra note 28 .

32 Harrison and Laine, After Repeal (1936) 193. See also Nat. Conf. of State Liquor Administrators, Proceedings (1938) 93, id. (I939) 109-117.

${ }^{33}$ Distilled Spirits Institute, supra note 28.

${ }^{34}$ U. S. Dept. of Commerce, Survey of Current Business (June r940) 7.

${ }^{35}$ As calculated on calendar year basis by Distilled Spirits Institute, stipra note 28 .

${ }^{36}$ Rep. COMmissioner INT. Rev. (1937-1938, I939). 
On the face of these revenue figures, it does not appear that the present taxation of alcoholic beverages, taking the Federal Government and the states as a whole, is operating in the direction of increasing the consumption of the lighter alcoholic beverages at the expense of the heavier. Federal figures give, of course, an indication of the overall picture of alcoholic beverage consumption since all these beverages sold in the states are federal taxpaid.

Table I. U. S. Taxpaid Wrthdrawals ${ }^{37}$

\begin{tabular}{|c|c|c|}
\hline Still Wine & Distilled Spirits & $\begin{array}{r}\text { Fermented Malt } \\
\text { Beverages }\end{array}$ \\
\hline$\ldots \ldots \ldots \ldots 35,417$ & $5^{8,083}$ & 42,228 \\
\hline$\ldots \ldots \ldots \ldots \ldots \ldots, 47,474$ & $76,33^{\circ}$ & 48,75 \\
\hline$\ldots \ldots \ldots \ldots .62,035$ & 87,721 & 55,3 \\
\hline . $6 \mathrm{r}, \mathrm{I} 75$ & 85,949 & 53,9 \\
\hline . 67,376 & 92,427 & $5 \mathrm{I}, 8 \mathrm{I}$ \\
\hline
\end{tabular}

Analysis of taxpaid withdrawals indicates this more clearly. In 1936 the tax on still wines was reduced $50 \%$. In the following fiscal year, taxpaid withdrawals of still wines increased $14,500,000$ gallons or $31 \%$. Considering the reduction in tax, the gain becomes less remarkable, since in the fiscal year 1936 similar withdrawals had been $12,057,892$ gallons or $33 \%$ higher than in 1935 .

If the increase in wine withdrawals were the sole test of the overall wine-taxing program from the viewpoint of promoting the consumption of lighter beverages it would appear successful, since from I 935 to 1939 the increase in taxpaid withdrawals of wine amounted to $3 \mathrm{I}, 959,000$ gallons or $90 \%$. But this gain was not at the expense of spirits, for in the same period withdrawals of spirits increased $34,344,000$ gallons. In absolute figures, this is larger than the increase in wine withdrawals, though in terms of percentage increase, $59 \%$, it is less. Moreover, during the same period, beer withdrawals increased but $9,55^{8,000}$ barrels, and as a matter of fact, declined in $193^{8}$ and 1939 from a previous higher point in 1937 . These relationships in relative withdrawals exist in spite of the fact that the beer tax until July I, x940, remained at $\$ 5.00$, the still wine tax had been reduced $50 \%$ in 1936 and the spirits tax increased $121 / 2 \%$ in $193^{8}$.

Although the statistics of withdrawals and, inferentially, consumption of spirits, wine and beer do not indicate any swing to the lighter beverages, a comparison of present and pre-Prohibition figures shows a decline in per capita consumption of both spirits and beer. (See Table II.)

The decrease in the consumption of spirits and beer in the period since I 900 is accentuated by the fact that in 1900 and I905 there were three, in I9ro six, and in I9I5 eight dry states. Today there are no totally dry states, and only three, Kansas, Mississippi and Oklahoma, prohibit the sale of alcoholic beverages other than those of very light alcoholic content. Wine consumption is higher now than in any of these years except I9ro. The sharp drop in I9I5 is due no doubt to the fact that

${ }^{37}$ Compiled from the Annual Reports of the Commissioner of Internal Revenue. Wines and spirits in thousands of gallons; fermented malt beverages in thousands of barrels. 
Table II. Per Capita Consumption of Alcoholic Bevernges ${ }^{38}$

\begin{tabular}{|c|c|c|c|}
\hline & $\begin{array}{c}\text { (in gallons) } \\
\text { Distilled Spirits }\end{array}$ & Wine & Beer \\
\hline 1900 & $\ldots \ldots \times .26^{2}$ & .40 & 16.05 \\
\hline I905 & 1.42 & .42 & I8.27 \\
\hline rgro & .. I.44 & .66 & 20.03 \\
\hline r9I5 & . . 1.28 & $\cdot 33$ & I8.68 \\
\hline I939 & .94 & .585 & 12.27 \\
\hline
\end{tabular}

prior to I9I4 wine bore no excise tax. At the present time it is the only one of the three beverages which has climbed back to around its average pre-Prohibition consumption. In view of this period-to-period comparison of consumption statistics, it appears that the combined federal-state alcoholic beverage tax programs on an overall basis, has not been ineffectual from the standpoint of those who recommended that "fundamental motives . . . be broadly social, not narrowly fiscal."

Whether the recent increases in rates under the Revenue Act of 1940 will cause any change in present trends is problematic. As among the three classes of alcoholic beverages, a change, if any, should favor the consumption of the lighter beverages because of the differentials in the increases, which are as follows: beer, $20 \%$ increase; spirits, $33 \frac{1}{3} \%$; and wine, 20 to $50 \%$. However, it has been pointed out that in the I935-I939 period, withdrawals of spirits increased more than wine, in spite of the fact that the former bore an increase in tax rate while wines were favored by a reduction.

In the report of the Secretary of the Treasury for the fiscal year 1939, printed before the increased rates were imposed by the Revenue Act of 1940, it was estimated that alcoholic beverage taxes would yield $\$ 615,500,000$ in the fiscal year I940. Of this increase, it was estimated spirits would furnish $\$ 18,000,000$, beer $\$ 15,000,000$ and wines $\$ I, 000,000$, while floor taxes of $\$ 5,000,000$ would not recur. ${ }^{30}$ Actual receipts from alcoholic beverages taxes in the fiscal year $x 940$ were $\$ 624,000,000$. But most significant is the fact that distilled spirits excises increased $\$ 31,000,000$ as compared with the estimate of $\$ 18,000,000$, while beer excises increased only $\$ 4,800,000$ against an estimated increase of $\$ 15,000,000 .^{40}$

These figures seem to furnish another indication that although the combined federal-state tax program has limited alcoholic beverage consumption on the basis of pre- and post-Prohibition comparisons, yet as between the various classes of alcoholic beverages, the rates are not such that the consumption of the lighter beverages is encouraged and favored.

\section{Taxation and the Enforcement of Alcoholic Beverage Laws}

In determining its alcoholic beverage tax program one of the principal considerations facing Congress was that of setting the tax rate at such a point that the

\footnotetext{
ss I $900-1915$, Joint Hearings 386; 1939, spirits and beer calculated on basis of excise taxes (beer imports in 1939 not included; wine figure from Wine Institute, Consumption of Wine by States (1939).

30 REP. SEC. TREAS. (1939) 404.

${ }^{60}$ Bur. of Int. Rev., Press Release, No. 138, Aug. 30, 1940.
} 
price to consumers would be low enough to discourage bootleg competition. As was to be expected, there were various opinions concerning the price at which the illicit goods could be marketed to retailers. These estimates ranged from $\$ \mathrm{r} .00$ to \$4.20 per gallon. ${ }^{41}$ The states were faced with a similar problem. After the federal rates were determined, and since all the license states subsequently imposed their own taxes on spirits, observers watched with interest the ensuing effort to oust the bootleg trade which gained such a foothold during Prohibition days.

Table III. Federal Enforcement Statistics, ${ }^{42}$ r935-1939

\begin{tabular}{|c|c|c|c|c|}
\hline & & Seizures & & Arrests \\
\hline & Stills & Spirits & Mash & \\
\hline I935 & $\ldots I_{5,712}$ & 863,375 & $21,373,107$ & 31,625 \\
\hline 1936 & $\ldots \ldots \ldots \ldots \ldots \ldots r 5,629$ & 730,646 & $I_{4}, 67 I, I_{4} 6$ & $3^{I}, 504$ \\
\hline 1937 & $\ldots \ldots \ldots \ldots \ldots \ldots \times x 6,142$ & 476,521 & $12,365,224$ & 29,477 \\
\hline 1938 & $\ldots \ldots \ldots \ldots \ldots \ldots r 1,407$ & 344,668 & $7,553,848$ & 25,867 \\
\hline I939 & $\ldots \ldots \ldots \ldots \ldots \ldots$ I2,059 & 336,268 & $8,076,46 \mathrm{r}$ & 28,884 \\
\hline
\end{tabular}

The table shows the seizures and arrests made for violations of federal alcoholic beverage laws by the Alcohol Tax Unit of the Bureau of Internal Revenue from July I, 1934 to June 30 , I939. The drop in seizures of stills and presumably in the scale of violation has been especially marked since I937. The amount of distilled spirits seized has steadily decreased year by year, and seizures of mash dropped in every year but one. The absence of relative decreases in the number of arrests might be an indication that bootlegging tended to become a field of comparatively small scale operations. There is no data in the Commissioner's report as to the number of arrests connected with the manufacture or sale of illicit liquor, but some other types of federal law violations make up part of the total arrests.

The drop in seizures since I937 is especially interesting in view of the opinion expressed at the Congressional hearings held in December I933 that it would take about three years to eliminate organized bootlegging. ${ }^{43}$ Since there has been no letdown in enforcement, the inference is that bootlegging on a large scale has been brought under control.

The developments in I939 further substantiate this. After reaching a low point in $193^{8}$, seizures of stills increased in 1939 . On the surface this rise might appear to be related to the increase in the tax on spirits from $\$ 2.00$ to $\$ 2.25$ per gallon. The Commissioner of Internal Revenue, however, in commenting on the point, ${ }^{44}$ attributed the increase to a shift of enforcement efforts to areas "where the typical violator operates on a small scale." In other words, the investigational personnel during this period was augmented and the increase in seizures represents better en-

\footnotetext{
1 Joint Hearings, 35, 127, 139, 255.

${ }^{13}$ Compiled from Annual Reports of the Commissioner of Internal Revenue. Spirits and mash in gallons.

"3oine Hearings, 42. "REP. (1939) 3 I.
} 
forcement in that area rather than an increase in violations in the country as a whole. ${ }^{45}$

In view of the fact that the combined 1939 federal-state excises on spirits ran as high as $\$ 4.25$ per gallon (Delaware, New Mexico, Vermont) and $\$ 4.45$ per gallon (Maine), this record of enforcement seems impressive. It should be recalled, in this connection, that at the Congressional hearings in 1933 there was quite general agreement that a combined federal-state excise of around $\$ 2.60$ per gallon was the highest that could be safely imposed if the illicit trade was to be brought under control. ${ }^{46}$

Some, and perhaps a great part of the stringency of this enforcement is due to the control under the act of June $18,1934,{ }^{47}$ which the federal authorities exercise over the materials commonly used in the illicit production of distilled spirits. The Commissioner of Internal Revenue credits a number of seizures to information obtained from distributors of such raw materials. ${ }^{48}$ Thus, even though higher excises are in effect than before Prohibition, the development of new techniques of administrative enforcement has resulted both in apparently successful control of the organized illicit traffic and maintenance of the public revenue. The tremendous strides that have been made in enforcement procedure are best illustrated by a comparison with the $1862-1870$ period. In 1865 the spirits tax was increased to $\$ 2.00$ from a low of $20 \mathrm{c}$ in the first part of the previous year. In the fiscal year 1864 the yield was $\$ 30,000,000$, but in 1865 it dropped to less than $\$ 19,000,000$. ${ }^{40}$ Part of this decline may be attributed to the fact that no floor tax was imposed and production was quickened before the new rates went into effect. But one student of this problem comments on the fact that the number of distilleries in the country increased "just in proportion as the tax on spirits was augmented," their operators undoubtedly tempted by the profits in illicit distilling under a $\$ 2.00$ tax..$^{50}$

An indication of the difficulty tying the tax rate on spirits to control of the illicit traffic is afforded by Table IV relating state tax increases and enforcement statistics.

In each of the six states mentioned there were increases ranging from $4 \mathrm{Ic}$ to $65 \mathrm{C}$ per gallon. Yet seizures of stills by federal authorities and arrests for violations of federal liquor laws show $x 6$ declines as against 7 increases.

In spite of enforcement statistics, however, opinion is by no means in agreement as to the success of the campaign against the illicit trade. One study estimated that in 1935 bootleg production reached 40,000,000 gallons or about half the amount of distilled spirits withdrawn tax paid. Raw materials may be bootlegged, the study points out, or higher priced materials not so likely to be checked under the Government's raw material control program may be substituted. ${ }^{51}$ State officials, while

\footnotetext{
15 Rep. Sec. Treas. (1939) I54.

${ }_{4}^{4} 8$ STAT. I020, 26 U. S. C. \$1222.

"Toint Hearings, 36, 153 et passim.

${ }^{68}$ ReP. (1939) 31; (1938) 36. See also ReP. (1937) 32; (1936) 32; (1935) 28.

${ }^{10}$ Shultz and Caine, op. cit. supra note 2, at 307-308.

${ }^{50}$ Wells, op. cit. supra note 8 , at 46 .

${ }^{61}$ Harrison and Laine, op cit. stipra note 32, at 201 et seq.
} 
Table IV. Tax Rates and Enforcement Statistics ${ }^{52}$-Selected States

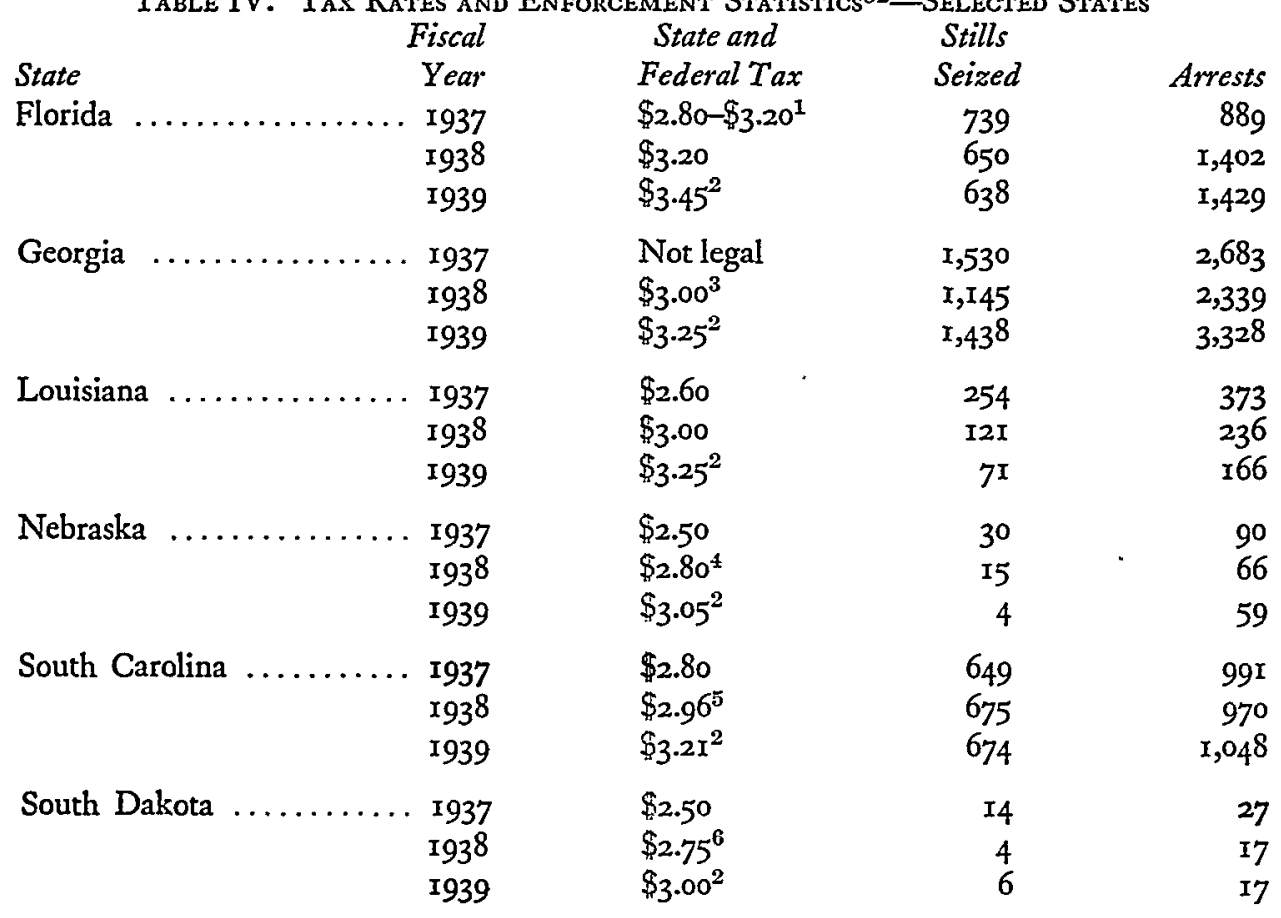

${ }^{2}$ State tax $80 \mathrm{c}$ to June 1937 ; $\$$ 1.20 after that date.

${ }^{2}$ Federal tax $\$ 2.225$ effective July I, 1938; prior rate \$2.00.

${ }^{3}$ Sale legalized effective Feb. 1938; state tax \$1.0o.

- State tax 5oc to April 1937; 8oc after that date.

"State tax 8oc to May 1937; $96 \mathrm{c}$ after that date.

${ }^{\circ}$ State tax $50 \mathrm{C}$ to July I937; $75 \mathrm{C}$ after that date. In addition, effective July 1937, distillers and wholesalers were required to pay a tax of $10 \%$ of their gross receipts.

acknowledging the manner in which the federal officials work with them in enforcement problems ${ }^{53}$ have admitted the danger of the bootlegger and stressed the importance of lower federal and state taxes in removing the incentive behind the continuance of the illicit trade..$^{54}$

The estimate of the illegal production of 40,000,000 gallons of spirits in 1935 is only about one third less than the Bureau of Prohibition's estimate for I930 which was $60,000,000$ gallons. The total quantity in circulation from all sources, including imports from other countries, was then estimated to be about $70,000,000$ gallons. ${ }^{55}$ In that period, however, there were seizures of 16,180 distilleries, 8,138 stills, $4,152,920$ gallons of malt liquor, and $34,183,427$ gallons of mash. ${ }^{56}$ On the basis of the number of seizures made at the present time (Table III) the estimate of illicit production of 40 million gallons seems out of line when compared to the I930 figure which, by

${ }^{2}$ Compiled from Public Revenues from Alcoholic Beverages, supra note 28, and the Annual Reports of the Commissioner of Internal Revenue for x 937-1939.

${ }^{63}$ Nat. Conf. State Liquor Administrators, Proceedings (1937) 55-57.

ad Id. (1938) 191, (1939) 123.

sE Nat. Comm. on Law Obs. and Enf., supra note I, at I 42.

co Ibid. 
the way, was about half the pre-Prohibition consumption. Taking together the trend of seizures, the raw materials control program and the continued rise in revenue receipts, it seems reasonable to conclude that even at these rates there is effective enforcement.

The states have a peculiar bootleg problem of their own which occurs because of the differences in rates of tax among the states and because liquors sold for shipment to other states are generally exempt from the excise tax. Thus, where adjacent states have tax rates with a sufficient differential, there will be attempts to buy liquor in the lower tax states for transportation into the others. ${ }^{57}$ Or, it may happen that alcoholic beverages may be purchased taxfree in one state and brought to another for illicit sale. To overcome this, the states have adopted the practice of reporting out-of-state shipments to the state of consignment in order that the officials of the latter state may check to see whether the proper tax has been paid. ${ }^{58}$

Whether the legal liquor traffic can hold its own despite the fairly heavy increases in tax in some of the states ${ }^{59}$ during 1939, plus the one third federal increase in 1940, is another problematic situation. As a matter of fact, most of these state-enumerated increases were in effect during part of the fiscal year 1938-1939, and in that period federal receipts from alcoholic beverage taxes exceeded Treasury estimates by $\$ 2,000,000$, the revenue from the distilled spirits excise alone exceeding estimates by $\$ 20,000,000 .^{60}$ This was true, moreover, in spite of the fact that the federal rate increased $25 \mathrm{c}$ in that year. But there is little doubt that with a combined tax rate on spirits of around $\$ 5.00$ in some states, a stronger incentive to illicit dealers will be furnished.

\section{Alcoholic Beverage Taxation and Public Finance}

The taxation of the alcoholic beverage traffic has played an important role in the revenue system at various periods in our national policy. Indeed, a consideration of the occasions on which the Federal Government enacted taxes of this type indicate that the raising of revenue was the predominant if not the sole motivating factor in pre-Prohibition times.

The first national internal tax on alcoholic beverages was enacted in $179 \mathrm{~g}$ in order to furnish revenues for the program of expenditures pledged by the Federalists in I789, for which the customs duties were seen to be insufficient. ${ }^{01}$ This was a tax on whiskey graduated as to proof and with a differential favoring the use of domestic raw materials. The rates on low proof spirits were $g c$ and IIc respectively for whiskies distilled from domestic and imported materials.

\footnotetext{
${ }^{27}$ See discussion, Nat. Conf. State Liquor Administrators, Proceedincs (1938) I6z, and supra p. 704 .

${ }^{58}$ Id. 166-170. In addition the states sometimes find that federal tax-paid liquor is sold without payment of the state tax. To the states, of course, this is just as much bootlegging as is the sale of spirits produced in illicit stills. To what extent this practice is carried on, however, it is not possible to say.

${ }^{50}$ Ark., $80 \mathrm{c}$ to $\$ \mathrm{r} .12$; Conn., 60c to \$r.00; Md., \$1.00 to \$1.15; Mass., 40c to $95 \mathrm{c}$ for 2 ycars; N. C., gross sales tax raised from $7 \%$ to $81 / 2 \% ; N$. D., additional transactions tax of $7-8 \%$; R. I., $75 \mathrm{C}$ to $\$ \mathrm{r} .00$; S. C., $96 \mathrm{C}$ to $\$ \mathrm{r} .28$; and Vt., $23 \mathrm{C}$ to $35 \mathrm{C}$ per pint. Distilled Spirits Institute, supra note 28 .

${ }^{80}$ Rep. Sec. Treas. (1938) 456; (1939) 404 .

${ }^{-1}$ Shultz and CaINe, op. cit. supra note 2, at 107-108.
} 
Discontinued in 1802 together with the other internal excises, it was not until the War of 1812 that the tax was again imposed. Then increased expenditures, coupled with a drop in customs receipts, made necessary new internal taxation. A special session of Congress in 1813 enacted license taxes on stills and on the retailing of wines and spiritous liquors. ${ }^{62}$ In effect only a few years at this time, alcoholic beverage taxes were not used again until 1862 when other war demands were felt. From a $20 \mathrm{c}$ per gallon rate on spirits in 1862 there were successive increases to $\$ 2.00$ per gallon in $1865^{.63}$ In 1868 the rate was cut to $50 \mathrm{c}$ but the tax by then had assumed a permanent place in the federal revenue system. Shortly before the turn of the century, the rate had climbed to $\$ \mathrm{r} . \mathrm{Io}$, the total alcoholic beverage tax yield increasing from $\$ 51,000,000$ in 1869 to $\$ 230,000,000$ in 1913 . In the next year, 1914 , a tax was imposed on domestic wines which with other excises was to replace the loss of receipts caused by the outbreak of the World War. Then in the Revenue Act of $x 917$ taxes on alcoholic beverages were raised to yield an estimated $\$ 200,000,000$ additional.

In all these instances, there seems little doubt that the primary objective of the tax was to raise needed revenues. The rate of $\$ 6.40$ imposed under the Revenue Act of 1918 (enacted in February 1919) in distilled spirits withdrawn for beverage purposes is probably the only exception since it was effective in the interim between the ratification and the effective date of the Eighteenth Amendment. It is paradoxical that under this high rate which has been called a penalty tax, receipts from the spirits tax were the highest ever recorded, $\$ 354,000,000$, even though the number of gallons domestically consumed shrank to 84 million from a total of $x 67$ million gallons two years previously in $1917 .{ }^{64}$ With this situation may be compared that existing in $1864-65$ when after a sharp increase in rate to $\$ 2.00$ per gallon receipts dropped from $\$ 30,000,000$ in 1864 to $\$ 19,000,000$ in $1865^{65}$ As has been observed, part of this decrease may be attributed to the fact that the tax was imposed on new production only and not also on floor stocks as is the case today. As a result, production was stepped up when a rate increase was believed probable and manufacturers were able to make an additional profit, for, although they did not pay the government the increased tax, they did add it to the price when they released their stocks for sale to consumers. ${ }^{66}$

(a) Federal and State Revenues. After the repeal of Prohibition alcoholic beverage taxes again were called upon to produce revenue. Although it has been pointed out that this was by no means the only element considered, there can be no doubt that the tax has been a successful revenue raiser. In the fiscal year 1939 the yield to the Federal Government was $\$ 587,000,000$ and to the states $\$ 219,000,000$. The disappointing yields in the first years following Repeal were due no doubt to the facts: first, that the consumption of alcoholic beverages has not, even at the present time, reached its pre-Prohibition levels and the estimates were based on an annual con-

${ }^{02} I d$. 14I. ${ }^{03} I d .307 . \quad 04$ Joint Hearings, 326, chart I.

${ }^{\circ 0}$ Shultz and CaINe, op. cit. supra note 2, at 307. See also Wells, op. cit. supra note 8.

${ }^{00} I d .43$. 
sumption of around $140,000,000$ gallons of distilled spirits yearly which was equivalent to the pre-Prohibition taxpaid withdrawals; and second, that all states did not immediately legalize the sale of liquor.

\begin{tabular}{|c|c|c|c|c|}
\hline \multirow[b]{2}{*}{ Year } & \multicolumn{2}{|c|}{$\begin{array}{l}\text { (in millions of dollars) } \\
\text { Federal }\end{array}$} & \multicolumn{2}{|r|}{ State } \\
\hline & $\begin{array}{l}\text { Alcoholic } \\
\text { Beverages }\end{array}$ & $\begin{array}{l}\text { Percent of Total } \\
\text { Tax Collections }\end{array}$ & $\begin{array}{l}\text { Alcoholic } \\
\text { Beverages }\end{array}$ & $\begin{array}{l}\text { Percent of Total } \\
\text { Tax Collections }\end{array}$ \\
\hline & $\ldots 224$ & 35 & $2 I^{\circ}$ & 5.6 \\
\hline Igrg & $\ldots 483$ & 12. & 14 & 2.6 \\
\hline I937 & ... 594 & 22.3 & 218. & 7.2 \\
\hline 939 & $\cdots 5^{87}$ & $x 2.3$ & $2 \pi 8.5$ & 7.2 \\
\hline
\end{tabular}

The table shows the federal and state yields in dollars and in percentages of total tax revenues for selected pre- and post-Prohibition years. It is worthy of note that although both federal and state yields are larger in absolute amounts than in preProhibition days, the Federal Government now receives only about one eighth of its total tax revenues from this source as against one third; whereas these taxes contribute a slightly higher percentage of the total tax revenues of the states. ${ }^{68}$ In 1939 federal alcoholic beverages tax revenues were about two and a half times greater than in I9I5, while in the same period state revenues from this source increased ten-fold.

(b) Local Revenues. Accurate comparisons of pre- and post-Prohibition local revenues from alcoholic beverage taxes are difficult to make. In rgo2, localities received approximately $\$ 45,000,000$ from liquor licenses and in 1912 approximately $\$ 58,000,000^{69}$ Subsequent to 1912 , revenues of this type were included in the category of business license taxes but were not broken down by type of business. It has been estimated that the advent of Prohibition cost the states and localities about $\$ 100,000,000$ annually. ${ }^{70}$ On the basis of state collections of $\$ 20,000,0000$ in 1915 , the local collections would have been $\$ 80,000,000$, an increase of $\$ 22,000,000$ in the three years following I9r2. Perhaps the actual figure is somewhere between the two.

It is likewise quite difficult to make an appraisal of the relative importance of these tax revenues to local governments at the present time. In the chart "America's Taxes," "71 based on United States Treasury data, it is estimated that local governments in 1938 collected around $\$ 25,000,000$ from alcoholic beverages taxes, although this has been regarded as a low estimate. On the basis of estimated total local tax

\footnotetext{
${ }^{87}$ Compiled from Annual Reports of the Secretary of the Treasury, Financial Statistics of States 1937 (U. S. Bur. of Census), and State and Local Government Special Study No. 7 (U. S. Bur. of Census). Total tax collections are exclusive of payroll taxes.

${ }^{68}$ See Tax Administrators News, April 1940, for a graphic comparison of federal tax collections by sources; Feb. 1940, for a graph of the tax dollar of the states for 1939; Aug. 1940, for a graphic comparison of trends in U. S. taxes, federal, state and local by type of tax.

${ }^{60} 2$ Wealth, Debt and Taxatton (U. S. Bur. of Census, 1913) 462.

${ }^{70}$ Shultz and Caine, op. cit. stipra note 2 , at 542 .

${ }^{71}$ Tax Administrators News, Sept. 1939.
} 
receipts for 1938 of $\$ 4,531,000,000,{ }^{72}$ this would constitute only slightly more than one half of one percent.

The Distilled Spirits Institute has published estimates ${ }^{73}$ for 1937 -I939 local collections. These are somewhat higher in amount and for these years are as follows: 1937, \$33,574,638; 1938, \$31,772,279; 1939, \$32,835,899.

(c) Sharing of Taxes. The localities, however, besides their direct tax receipts also share in some states in the yields from state taxes on alcoholic beverage sales or licensing. Here again it is not possible to secure completely segregated figures. The Bureau of the Census reports a total of approximately $\$ 44,000,000$ of alcoholic beverage sales and license taxes shared by 18 states during $19377^{74}$ This does not include any profits from state monopoly systems. Another study reports that 22 states in r938 shared approximately $\$ 59,000,000$ with local governments but this amount apparently includes some monopoly system profits. ${ }^{75}$

The basis of sharing such taxes is, roughly speaking, generally in proportion to the amounts of revenue derived from the particular locality. This may be stated on a population basis, as a wet and dry ratio, in terms of the number of licenses issued and the receipts therefrom, or sometimes simply in proportion to the localities whence the revenue is derived. In one state, Oklahoma, the apportionment is made on the basis of scholastic enumeration. ${ }^{76}$

The estimated present direct tax collections of the localities plus their shares of state collected taxes brings the total close to the top estimate of $\$ 80,000,000$ annually received before Prohibition. In order to round out the local picture, however, another development must be taken into consideration.

In IgIg the states sought adjustments for the loss of revenue that Prohibition would bring. Income taxes were enacted, and corporation and inheritance tax rates were increased. Even though local revenues had been more sharply hit than those of the states, the substitute taxes were not adapted to local administration. The states, therefore, in many cases shared the proceeds of these new taxes with the localities. ${ }^{77}$ Consequently, the shared revenues which localities receive from these sources even at the present time must be added to direct and shared receipts from alcoholic beverage taxes in order to compare the pre-Prohibition local receipts with those of today.

(d) Earmarking of Taxes. State shares of alcoholic beverage taxes are often earmarked for specific purposes. Although it was strongly recommended that such receipts go to the general funds, this practice has not been generally followed. Twelve of the 32 license states have earmarked these revenues to the support of social welfare programs including old age pensions, relief of crippled and underprivileged

${ }^{72}$ U. S. Treas. Bull., Aug. 1939.

${ }^{73}$ Public Revenues from Alcoholic Beverages, 1937, 1938, I939.

"Financial Statistics of States 1937, 50.

${ }^{75}$ Merlin, American Taxes Shared and Allocated (Amer. Municipal Assn. and Fed. of Tax Administrators, 1938) 23.

${ }^{76}$ Id. 35 .

${ }^{7 \pi}$ Shultz and Caine, op. cit. sttpra note 2 , at 542. 
children, charitable institutions, and schools. ${ }^{78}$ Massachusetts and Tennessee reimburse localities for old age assistance expenditures with part of their collection. New York contributes a fixed amount to the New York City Police Pension Fund, and Louisiana requires localities to use a portion of their revenues for this purpose. Louisiana, Kansas, and North Dakota devote part of their total alcoholic beverage revenues to homestead exemption funds, while Wisconsin requires that receipts shared with localities go to reduce local property taxes. Minnesota's receipts go to the general fund but they must be used to redeem state certificates of indebtedness. Ten states require that collections go to the general fund for, expenditure therefrom without any earmarking. ${ }^{79}$

Financing by means of earmarked revenues is open to criticism on several grounds. The operations may be outside the budget and for that reason it is diffcult to plan a special program definitely tied up with the overall program of the state. Even where these receipts are estimated and carried in the budget, there is only a formal difference because if there are marked fluctuations in revenues in eithes direction, no administrative discretion may be exercised since amounts or percentages are fixed by statute.

Thus, when there is an excess of revenues over the actual requirements of the supported function, the money cannot be used for other purposes, and on the other hand, if revenues decline unexpectedly, the performance of the supported function may be severely handicapped.

While this is true of any earmarking finance, in some of the states it is especially dangerous. This is a consequence of the fact that the principal beneficiaries of these funds are various public welfare programs. Since a large part of the revenues are derived from excises on the sale of alcoholic beverages, it is probable that in subnormal years when larger numbers of people will require public assistance of one type or another, the sales of these products and consequently the revenues from them will decrease, just when they are most needed. An unexpected business decline of sharp proportions would no doubt play havoc with some of these programs.

Another objection to this type of finance is that pressure groups may exert influence on a particular' branch of the tax system without regard for the balance and adjustment of the whole. This pressure may come from groups interested in the proceeds earmarked, or from other groups who may point to the desirable functions the funds support, in order to attain some end of their own. In the case of alcoholic beverage taxation there is the possibility that the amount of revenue which could be derived would be made the sole motivation of the tax program. Or even if other social considerations involved in alcoholic beverage taxation were taken into account, a legislature might find itself in the position of having to balance, according to their respective desirabilities, the merits of more liquor revenues to pay higher old age

\footnotetext{
${ }^{78}$ Data from the summary on allocation of revenues in Public Revenues from Alcoholic Beverages (1939). These states are Ariz., Ark., Colo., Fla., Ga., Nebr., Nev., N. M., Okla., S. C., Tex., Wis.

${ }^{79}$ Cal., Conn., Del., Ill., Ind., Ky., Miss., Mo., N. J., R. I.
} 
pensions against the merits of uncontrolled traffic in spirits, for it would be on the latter basis that the most effective revenue yield would be forthcoming.

\section{Administration of Alcoholic Beverage Taxes}

Alcoholic beverage taxes are on the whole administered by personnel experienced in the revenue field. The federal tax is administered by the United States Treasury Department through the Bureau of Internal Revenue and its Alcohol Tax Unit. In 30 of the states general revenue officials are the administrators ${ }^{80}$ of the alcoholic beverage taxes, even though control and regulatory functions in connection with the traffic are vested in a liquor commission or other similar body.

Tax stamps are used by both the Federal Government and the states. Prior to I866 the federal tax had been assessed on the basis of producers' returns. In the first year stamps were used the yield from the tax on fermented malt beverages rose from $\$ 3,657,000$ to $\$ 5, \mathrm{I} 1_{5}, 000$. It is estimated that in the period prior to the use of stamps, there was an annual evasion of approximately $\$ 6,400,000$ in alcoholic beverage taxes of all types. ${ }^{81}$

Since r935 the Federal Government has required brewers to install meters to measure the quantities of beer sent through their pipe lines for bottling. These pipe line meters are supplemented by racking meters. Production of alcoholic beverages is closely checked by the Federal Government which has employees stationed at the producing plants. Approval of plans for licensed manufacturing or storage premises are also required in order that possibilities of frauds on the revenue may be guarded against as much as possible.

In addition to the federal, state and local cooperation in enforcement problems, mention has been made of the regular exchange of information among the states on shipments leaving one state for delivery in another. Since in many states sales for shipment outside the state are not required to pay the excise tax, this practice of exchanging information provides a check both for the exporting state and the importing state. This administrative procedure has recently been strengthened in the midwest region by a further regulation that taxfree sales for shipment into other states would be made only to persons licensed or authorized by the receiving state to deal in alcoholic beverages. ${ }^{82}$ This will, it is hoped, prevent most of the bootlegging over state lines because of tax rate differences.

\section{Summary}

Although the combined taxes on alcoholic beverages are much higher than before Prohibition, they yield correspondingly higher amounts of revenue. While the present taxation of these beverages does not appear to favor the consumption of the lighter alcoholic beverages to the detriment of spirits, it evidently has operated to reduce the per capita consumption of both beer and spirits as compared with the pre-Prohibition

\footnotetext{
${ }^{80}$ Tax Administrators News, April I940. $\quad{ }^{81}$ WeLLs, op. cit. supra note 8, at $4 \mathrm{r}$.

${ }^{82}$ Cooperative Commissions in Action (April 1940) State Government 7o.
} 
years. At the same time the per capita consumption of wine is slightly above the average before Prohibition.

Despite the fact that there is no unanimity of opinion, there is reasonably convincing evidence to indicate effective enforcement of the liquor laws. Considering the high rates of tax that are imposed by both federal and state governments, the enforcement and revenue statistics are much more impressive than were predicted six or seven years ago when the matter of effective tax rates was considered in connection with pending legislation in Congress and in the state legislatures.

The Federal Government collects from these taxes about two and one half times the amount it did in normal years before Prohibition, while the states collect about ten times as much. These amounts constitute a smaller percentage of total federal tax revenues than in the prior period but a slightly larger percentage of total state tax collections. Taking into consideration direct collections and receipts from shared taxes and license fees on alcoholic beverages, together with receipts from other taxes shared as replacement revenues after Prohibition, the local governments receive about the same amounts today as they did before Prohibition. These revenues, however, furnish a very small portion of their total tax revenues.

It is a not uncommon practice for the states to earmark all or part of their alcoholic beverage tax revenues for the support of various social welfare programs. This seems to be undesirable both as a matter of budgetary practice and because of the danger of confusion of issues in determining what is most socially desirable for the community as a whole, especially where alcoholic beverage tax revenues are used for school or welfare programs. 